\title{
Nexus Between Entrepreneurship Education and Employability Skills of Tertiary Institution Students in Ilorin Metropolis
}

\author{
Aliyu Shehu Ahmed ${ }^{1}$ \\ Isiaka Abdulakeem Abiodun ${ }^{2}$ \\ Ibitomi Taiwo ${ }^{3 *}$ \\ Eke Tobias ${ }^{4}$ \\ Kwara State College of Education, Ilorin, Nigeria ${ }^{1}$ \\ University of Ilorin, Kwara State, Nigeria ${ }^{2}$ \\ Achievers University, Owo, Ondo State, Nigeria ${ }^{3}$ \\ Kogi State university, Anyigba, Nigeria ${ }^{4}$
}

\begin{abstract}
This study examines nexus between entrepreneurship education and employability skills of tertiary institution students in Ilorin metropolis. To establish this, two research questions were raised for the study. The target population for the study comprised students of Kwara state College of Education, Ilorin. One hundred and eighty students were randomly selected. A structured questionnaire was designed as the instrument for data collection. Regression analysis statistical method at 0.05 level of significance was used to test the formulated hypotheses. The study revealed that entrepreneurship curriculum contents contain information on how students can identify and shape opportunities, new business concepts and bring through entrepreneurship among students of tertiary institution in Ilorin Metropolis. This study concluded that entrepreneurship education is a good policy on employability skills acquisition among students which makes them to be self-sustenance after graduation. The study recommended among others that entrepreneurship lecturers should introduce and use innovative/modern methods in teaching students of higher institutions the art and practice of entrepreneurship. This can be achieved by ensuring that right facilities are in place and the lecturers must be qualified and equipped with adequate and updated knowledge and skills.
\end{abstract}

Keywords: Curriculum, Entrepreneurship, Education, Employability skills, Ilorin

*Corresponding author: Ibitomi Taiwo; Email: prof4real4all@gmail.com

DOI: https://doi.org/10.37227/IJEKM-2021-12-1168

\section{Introduction}

The increasing rate of unemployment and the slow pace of economic development in Nigeria has been persistent despite the abundance endowment of both human and natural resources in the country. However, unemployment is not unique to Nigeria or developing nations; it is however an aged long global issue hence it has been a usual trend in many countries to find students of tertiary institutions not able to perform well academically and 
also be employable after graduation (Twumasi, 2013). In proffering solution to the global crisis of unemployment, stakeholders and policy makers in developed countries such as United States of America, England and Germany clamoured for a more focused educational system that is channeled towards acquisition of vocational and technical skills to enhance smooth transition into jobs for school leavers particularly graduates of tertiary institutions. This is as a result of the fact that education is key to the development of any society particularly because the goals of wealth creation, poverty reduction and value reorientation can only be attained and sustained through an effective and efficient educational system which impacts relevant skills, knowledge, capacities, attitudes and values into individuals (Agi \& Yellowe, 2013).

Agi and Yellowe (2013) posited that education is seen as the most important instrument of any fundamental changes particularly with regards to the achievement of economic goals such as entrepreneurship development, job creation and poverty eradication, especially in the Nigerian context. The National Economic Empowerment and Development Strategy (NEEDS) (2004), gives credence to the role of education in the development of self-reliant abilities and entrepreneurship skills in individuals. Therefore, the role of education as regards entrepreneurship development in Nigeria cannot be overemphasized particularly in the tertiary institution. Thus, Ajayi and Afolabi (2009) affirm that tertiary education plays a critical role in relations to economic development of a nation. The management of economies today call for individuals that are enterprising, widely knowledgeable and able to effectively manage risks and uncertain situations (Enu, 2012). The fast-paced nature of the economies further mounts pressure on tertiary institutions in Nigeria to meet up with the growing needs and expectations of students and the society in order to ensure self-reliance, job creation and economic and development (Olorundare \& Kayode, 2014).

Graduate employability skills have now become issues that is raising global concerns due to the increasing number of unemployable graduates whose acquired skills are suspicious making it difficult for them to be recruited nor self-employable. The reasons for this include admission policy, poor funding and sorting syndrome among others (Dragoni, 2019). However, many countries are facing economic challenges at the moment and hence according to literatures immense pressure is now being put on higher education to produce quality graduates that can turn around economies with their specialist knowledge and skills.

Moreover, the aim of entrepreneurship education in tertiary institutions is to inculcate employability skills and attitudes in students to motivate entrepreneurial intentions or considerations of entrepreneurship as a career by undergraduates (Middleton, 2020). Although, entrepreneurial intention is the primary step towards the creation of a new venture in the entrepreneurial process, individuals already engaged in entrepreneurship unequivocally have a higher possibility of owning a business venture in future.

One of the harsh realities of the Nigerian society today is that there are more job applicants than the available slots both in the public and private sectors of the economy. This is as a result of the unconducive economic conditions namely lack of electricity, poor road network, insecurity, ranging from banditry, terrorism and secessionism among others which have caused the close down of many companies and thereby throwing many graduates into the labour market to seek for the unavailable unemployment slots. However, it is also quite unfortunate that our school system produces "quarter baked' graduates, 
majority of them are unemployable because of lack of skills and competency that is germane for self-sustenance. Thus, entrepreneurship education is to stimulate students' interest to perform as entrepreneurs; it is therefore, against this background that the study intends to examine the impact of entrepreneurship education and employability skills of tertiary institution students in Ilorin metropolis.

The general objective of this study is to examine the nexus between entrepreneurship education and employability skills of tertiary institution students in Ilorin metropolis. Specifically, the study is carried out to fulfill the following objectives;

i. to determine the employability skills acquired by the students during the course of instruction.

ii. to ascertain the level of students' performance in entrepreneurship education and their employability skills.

The research questions were set in line with the objectives of the study which includes;

i. what are the employability skills acquired by the students during the course of instruction?

ii. is there any relationship between students' performance in entrepreneurship education and their employability skills?

The result of this study will provide a guide for university managements on the formulation and implementation of policies, consistent with engagement in innovative activities and entrepreneurial development of undergraduates in tertiary institutions. The findings of this study will facilitate the development of entrepreneurial skills and aptitudes in Nigerian tertiary institutions students, which in turn will motivate the propensity for job creation and reduction in graduate unemployment.

The study focused on students of Kwara State College of Education, Ilorin, who are enrolled in the NCE business education programmes because of their proximity and commitment to entrepreneurship education among other students of higher schools in Kwara State.

\section{Literature Review}

\section{Concept of Entrepreneurship Education}

According to Fretschener and Weber (2013), the primary goal of entrepreneurship education in tertiary institutions is to empower graduates regardless of their course of study with skills that will enable them to engage in income-producing business, whether they are able or not able to secure paid employment, whether in the public or private sector. Education in entrepreneurship transforms graduates from job seekers to creators of jobs (Bassey \& Archibong, 2005). In 2006, Nigerian universities began offering courses in entrepreneurial education as part of their core curriculum (Agbonlahor, 2016). Graduates who have the entrepreneurial skills needed in the private sector can also start their own enterprises and subsequently hire people as a result of including entrepreneurship instruction in higher institutions. Educating young people in entrepreneurship is a responsibility that must be fulfilled to build their character, attitude, and vision. According to Fayolle, (2009), Entrepreneurship education encompasses all activities that aim to cultivate entrepreneurial mindsets, attitudes, and abilities (such as idea generation, startup, growth, and innovation) in a variety of contexts. 
Students who receive entrepreneurship training are more likely to go on to successful careers in the field (Mahendra, Djatmika, \& Hermawan (2017). UNESCO (2008) stated that entrepreneurship education is comprised of a wide range of experiences that teach students how to access and transform a wide range of diverse opportunities. It extends beyond the creation of a firm. It's about teaching students how to anticipate and respond to changes in society. The development of a nation's education system is the most important factor in its success (Maina, 2013). The general belief is that education has a favorable impact on entrepreneurship (Kuttim et al, 2014). To begin with, Shigeru Fijii established the first entrepreneurship program in Japan at Kobe University (Mwasalwiba, 2010). There has been an explosion in the number of academic institutions offering courses in entrepreneurship (Fretschener \& Weber, 2013). There is increasing evidence that entrepreneurship can be taught in postsecondary institutions (Hafiz \& Sa'ad, 2015). Education in entrepreneurship has no agreed-upon term (Valerio, Parton, \& Robb, 2014).

Education in entrepreneurship aims to equip students with the skills and motivation to succeed in a range of business environments. According to Ayatse, (2013), referenced by Chukwudi and Nwosu (2018), the framework of entrepreneurship education is as follows:

i. Offer vocational training to young people so they can be self-employed and goaloriented.

ii. Give the young people who have graduated from the programs the skills they need to be imaginative and creative in their search for new business prospects.

iii. To act as a stimulant for the growth and development of the economy.

iv. Provide graduates from postsecondary institutions with proper risk management training in order to ensure that bearing is practicable.

v. To lower the high poverty rate.

vi. It's also important to generate new jobs.

vii. Migration between rural and urban areas is decreasing.

viii. Ensure that young graduates receive adequate training and support so that they can begin a career in small and medium-sized businesses.

ix. Proud youngsters and adults will be encouraged to persevere in any entrepreneurial endeavour they take on as a result of this program.

$\mathrm{x}$. Make the transition from a traditional economy to one based on contemporary industrial methods as easy as possible.

\section{Education and Entrepreneurship Development in Nigeria}

Education is one of the most effective tools for human capital and societal development because no nation can attain an appreciable level of development above the level of her education (Orji \& Job, 2013). Education is very central to the training and development of human resources in any nation through transmission of suitable skills, knowledge, capacity building, attitude and value re-orientation employed in the transformation of individuals, communities and nations at large (Boyi, 2014).

Hence, education is seen as the most important instrument of any fundamental changes particularly with regards to the achievement of economic goals such as entrepreneurship development, job creation and poverty eradication, especially in the Nigerian context (Agi \& Yellowe, 2013). The National Economic Empowerment and Development Strategy (NEEDS) (2004), gives credence to the role of education in the development of self-reliant abilities and entrepreneurship skills in individuals. Therefore, 
the role of education as regards entrepreneurship development in Nigeria cannot be overemphasized. Ibitomi and Adeleke (2020) asserted that education in entrepreneurialism is an excellent way to encourage young people to become more self-reliant and capable of creating value rather than relying on others to do the work they need done.

\section{Concept of Graduate Employability}

A graduate's employability is defined by Kim (2012) as the ability to obtain and maintain employment through a wide range of personal characteristics and skills. According to Knight and Yorke (2004 in Ndlovu, et al. 2016), graduate employability is the ability to find work, perform well at a job, and advance within or between jobs. Employability can be defined as the ability to get a job (the most popular definition), in which students are only taught knowledge and skills relevant to the job they want to do (Republic of south Africa, 2011). There is a problem with this perspective because it doesn't include the soft talents that employers are searching for in graduates (Weissemann, 2012; Kim, 2012). In today's highly competitive labor market, employers are more concerned with soft skills, such as problem solving, flexibility and adaptability, teamwork, confidence and integrity, analytical skills, and communication skills, than they are with academic qualifications, according to research (Kim, 2012; British Council, 2015). Employability for graduates can be seen as the non-market characteristics, such as forming public good ideals, appreciating diversity, and solving problems that show a prospective employee as a productive team member (British council, 2015; Kim, 2012).

A study by Samuel et al (2012) found that in addition to academic qualifications, employers are now looking for non-academic skills such as analytical skills, communication skills, good interpersonal and social skills, teamwork, motivation, time management, problem solving, among many others. A study by Aida, Norailis and Rozaini (2015) concluded that diplomas and degrees are no longer worth what they used to be on the labor market in order to improve the career prospects of a graduate; it is now soft skills that matter. Weissmann (2012) also discovered that businesses are looking for people with both hard skills (professional, technical, and administrative knowledge and skills) and soft skills (the ability to work effectively with others). It's not just the economics that has an impact on how many grads are able to land a job; rather, it's their soft skills that determine who gets hired, according to Garwe (2013). These findings from Archer and Davidson (2008 in Ndlovu, et al. 2016) and Popo and Barckhuizen (2010) support Garwe's (2013) assertions. These researchers found that factors such as a lack of technical or industryspecific skills, knowledge, and capabilities as well as interpersonal and teamwork abilities and self-motivation are all important in the workplace.

Employability and work-readiness are often used interchangeably. Work-readiness, according to Yorke (2010), is a set of conditions necessary for obtaining one's first job, whereas employability is a set of skills required but not sufficient for landing a job. Graduates must be both employable and work-ready in order to have a greater chance of finding a job after graduation (Sachs, Rowe, \& Wilson, 2017). In recent years, ideas about what graduates need to be considered work-ready have shifted from a narrow focus on technical abilities and traits to one that includes non-technical aspects like networking (Bridgstock, 2017) and building a professional persona (Zegwaard, Campbell, \& Pretti, 2017). 
It is important to distinguish between 'potential employability and realized employability,' which both focus on an individual's 'potential' to attain desired work (via the development of adequate human capital) (Wilton, 2014).

This special issue focuses on the first. According to most current concepts of employability, it is defined as the ability to operate well in a team as well as in a specialized field (e.g. engineering or law) and to possess personal traits that are desirable in the workplace (e.g. self-confidence, resilience, discipline). The ability to identify, acquire, adapt, and continually enhance the skills, understandings and personal attributes that make graduates more likely to find and create meaningful paid or unpaid work that benefits themselves, the workforce, the local community, and the economy is called employability, according to Oliver (2015). Similar "skills" were identified by other researchers. As an illustration, Smith, Ferns, and Russell (2014) identified six dimensions of employability (also known as work-readiness): professional practice and standards; integration of theory and practice; lifelong learning and collaboration; informed decision-making; and commencementreadiness (confidence to begin a job in the discipline).) "The complexity of graduate workreadiness" has been better captured by broadening the definition of employability (e.g., Burke et al., 2016; Holmes, 2017), which has led to requests for more critical ways to understanding employability (e.g., Clarke, 2017; Holmes, 2017). (Jackson, 2015).

Students' perceptions of their own employability (and their ability to articulate it) as well as networking, global citizenship, and scholarship are all aspects of new perspectives on employability that take into account this transformation (e.g., Bridgestock, 2009; Jackson 2015;Mason, Williams, \& Cranmer, 2009; Wilton, 2014). "The need consequently for the integration of these diverse elements into a more holistic idea of graduate employability" has emerged despite broader interpretations of employability, which appear to be somewhat random (Jackson, 2016).

Finally, the quality of student learning, particularly the growth of students' employability skills, must be evaluated. An assessment of employability skills development requires careful consideration of the concepts of proximity and authenticity (Kaider, Hains-Wesson \& Young 2017), which has resourcing consequences for higher education institutions (Bilgin, Rowe, \& Clark, 2017)

\section{Tertiary Education and Entrepreneurship Development in Nigeria}

Ajayi and Afolabi (2009) affirm that tertiary education plays a critical role in relations to economic development of a nation. The management of economies today call for individuals that are enterprising, widely knowledgeable and able to effectively manage risks and uncertain situations (Enu, 2012). The fast-paced nature of the economies further mounts pressure on tertiary institutions in Nigeria to meet up with the growing needs and expectations of students and the society in order to ensure self-reliance, job creation and economic and development (Olorundare \& Kayode, 2014). Undergraduates in Nigeria's tertiary institutions are given both academic and practical entrepreneurship education as a way to cultivate the individual's desire and skill ( Ibitomi \& Adeleke, 2020)

\section{Theoretical Framework}

\section{Theory of Human Capital}

It was propounded by Berker (1964), chiefly assumes that formal education is essential and necessary to improve the productive capacity of a population. 
The ability of people in terms of productivity can be improved by increasing their educational attainment, according to the Human Capital Theory (HCT). According to human capital theorists, people who are educated are more productive than those who are not. Increasing the cognitive stock of economically productive human capability, which is a result of natural abilities and investment in human people, is the focus of HCT's emphasis. Proponents of the theory have viewed formal education as an investment in human capital that is equivalent to or even more valuable than the investment in physical capital (Woodhall, 1997).

According to Human Capital Theory (HCT), human capital investment leads to larger economic outputs, however it is difficult to verify and contradictory. Land, industries, and other physical assets used to be a major source of economic power. Labor was essential, but the company's worth grew as a result of the company's investment in capital equipment. Education and health care appear to be the key to enhancing human capital and raising the nation's economic production, according to modern economists (Becker, 1993).

Education in Western countries has recently been re-theorized under HCT as largely a means of generating economic output. Since the early 1960s, HCT has been the most influential economic theory in western education. It's becoming more and more important as a predictor of economic performance. The concept of human capital and numerous economic metaphors, such as technological change, research, innovation, productivity, education, and competitiveness, have been used to determine economic performance. In the past, however, education was not driven solely by economic considerations.

The importance of education and training in the emerging global economy is emphasized by HCT. Many established values and practices will be severely disrupted by the significant changes in the economy that have been implemented over the past few years in response to globalization, according to a recent assessment from the Organization for Economic Cooperation and Development (OECD). Higher education internationalization is described as a facet of globalization in another paper.

A nation's human development is mostly dependent on its physical and human capital. Recent social science research has therefore focused on human behavior and economic productivity in relation to behavioral sciences. Generally, human capital refers to the assets that each person creates in order to increase economic production. The policies of education and development are also important to human capital. There is a strong case to be made that an educated population is more productive than a less educated population. Boosting the cognitive stock of economically productive human capability is the focus of human capital theory, which emphasizes the role of education in increasing the productivity and efficiency of workers. Investments in human capital are perceived as equally or even more valuable than investments in physical capital by proponents of the theory of human capital.

According to Fagerlind and Saha (1997), considerable public expenditures on education in both developing and developed countries can be justified by HCT. Democracy and liberal progress are common themes in Western societies, and this philosophy fits in well with them. Its argument was founded on the idea that education, on both a macro and micro scale, had a positive economic return. Investing in human capital has been shown to have a positive impact on society's economic growth. Personal economic success and performance were considered as rewards for such an investment for individuals. Most 
economists agree that a country's economic and social progress is determined by its people resources, not its capital or material resources. The prosperity of nations is built on the foundation of human capital. This means that human beings are the active agents of production rather than capital and natural resources. This means that human beings are the active agents rather than capital and natural resources.

The theory of human capital must be applied to educational systems in order to improve human growth in society as a whole. Productivity is improved and maintained as a result of a larger and more diverse labor force. He claims that education contributes to economic growth and development by increasing the productivity of an already-existing workforce in a variety of manners Educational expenditures are viewed as an investment since they play a substantial effect in a nation's economic well-being. Individuals' human capital is increased, resulting in more societal output and higher individual worker pay. It improves their prospects of finding work, as well as their financial and non-financial wellbeing, while also allowing them to advance in their careers. As long as it's anti-traditional in nature, education can be a source of economic growth and development, as long as it empowers the individual and teaches him how and why to demand what he wants.

\section{Methodology}

This study adopted descriptive research design to examine the relationship between entrepreneurship education and employability skills of tertiary institution students in Ilorin metropolis. The target population are all the business education NCE students of the Kwara State College of Education, Ilorin. A multistage sampling technique was adopted for the study. The first stage involved purposive sampling which was used to select the tertiary institution used for this study. The school was chosen due to its proximity to the researchers and the relevance of the course of instruction to the research subject matter. The second stage involved stratified sampling technique which was used to categorize the study population (NCE students) in the selected tertiary institution different academic years. The last stage involved simple random sampling which was carried out firstly by assigning a consecutive number from 1 to the population number for the selected tertiary institution, secondly from the list of students in each academic year in the selected institution a sample was drawn using random number tables. Consequently, a total of 180 students were chosen from the selected department in the institution as sample size for this study.

The population consist of 180 students which were chosen from the selected department in the institution as the sample size for this study. In choosing the sample for the study, purposive sampling technique was used while simple random sampling technique was employed to select students who served as respondents to the questionnaire. The instrument used for this study is a 14-item and five-point Likert rating scale (strongly agree, agree, undecided, disagree and strongly disagree) questionnaire titled "nexus between entrepreneurship education and employability skills of tertiary institution students in Ilorin metropolis." The instrument was validated using face and content validity methods and it was equally subjected to test-retest method using Pearson Product Moment Correlation Coefficient method to determine the reliability coefficient of the instrument which was 0.74 .

The questionnaire was administered personally by the researchers on the respondents and the data collected were analysed, scored and subjected to statistical analysis using regession analysis statistical method at 0.05 level of significance.

International Journal of Education and Knowledge Management (IJEKM) 


\section{Data Presentation and Analysis}

Table 1: Regression analysis of the relationship between students' employability skills and the course of instruction acquired by the students

\begin{tabular}{|l|r|r|r|c|}
\hline \multicolumn{2}{|c|}{ Table 1: } & \multicolumn{3}{c|}{ Model Summary } \\
\hline Model & $\mathrm{R}$ & R Square & $\begin{array}{c}\text { Square } \\
\text { Square }\end{array}$ & $\begin{array}{c}\text { Std. Error of the } \\
\text { Estimate }\end{array}$ \\
\hline 1 & $.731^{\mathrm{a}}$ & .673 & .647 & .60488 \\
\hline
\end{tabular}

Source (Field Survey 2021)

a. Predictors: (Constant), Employability skills

From the regression analysis result shown in table 1 , it was found that: $R$ value is $(0.731)$, R-square (0. 673), adjusted R-square (0. 647) and the standard error of estimate is (0.60488).

The high value of $\mathrm{R}$ indicates a stronger relationship between employability skills and course of instruction values of the variables. In other words, the $\mathrm{R}$ value depicts that employability skills accounted for $(73.1 \%)$ of the variation in course of instruction. Also, the $\mathrm{R}^{2}$ value $(0.647)$ means that $64.7 \%$ of the variation in course of instruction was explained by employability skills. This implies that employability skills contributes about $64.7 \%$ to the skills acquired after the course of instruction while the remaining $35.3 \%$ is due to other variables that are not accounted for in the model.

Table 2:

ANOVA $^{\mathrm{a}}$

\begin{tabular}{|ll|r|r|r|r|r|}
\hline Model & & Sum of Squares & Df & Mean Square & F & Sig. \\
\hline 1 & Regression & 59.803 & 1 & 59.803 & 44.762 & \\
& Residual & 239.058 & 179 & 1.336 & & \\
& Total & 298.861 & 180 & & & \\
& & & & \\
\hline
\end{tabular}

a. Dependent Variable: Course of Instruction

b. Predictors: (Constant), Employability skills

The ANOVA table above shows that the $p$-value $=0.000<0.05$ (sig.). Since $p$-value $<$ 0.05 thus the rejection of the null hypothesis that employability skills does not significantly determine skills acquired after the course of instruction and the alternative that employability skills significantly determine skills acquired after the course of instruction.

\begin{tabular}{|c|c|c|c|c|c|c|}
\hline & & & & Coefficients $^{\mathrm{a}}$ & \multirow[b]{3}{*}{$\mathrm{t}$} & \multirow[b]{3}{*}{ Sig. } \\
\hline \multirow[b]{2}{*}{ Model } & & \multicolumn{2}{|c|}{ Unstandardized Coefficients } & $\begin{array}{l}\text { Standardized } \\
\text { Coefficients }\end{array}$ & & \\
\hline & & B & Std. Error & Beta & & \\
\hline & (Constant) & 2.901 & .191 & & 9.974 & .000 \\
\hline & GenderDiversity & .274 & .060 & .378 & 2.919 & .004 \\
\hline
\end{tabular}

a. Dependent Variable: Course of Instruction

Table 3 shows that the skills acquired after the course of instruction is equal to 2.901 when all other variables are held to zero. The skills acquired after the course of instruction would increase by 0.274 when there is an employability skills by one unit, while other variables remain constant. However, the result shows that employability skills has positive and significant effect $(B=0.378, t$-value $=2.919 \mathrm{p}<0.05)$. This implies that the skills acquired after receiving instruction in entrepreneurship education is as a result of employability skills included in the students' curriculum. This result is in line with the study of Bilic, Prkaand Vidovic (2011) that affirm that self-employment skills acquired by graduate is as a 
result of the quality of instruction given to students in employability skills by their lecturers.

Table 4: Regression analysis of the relationship between the students' performance in entrepreneurship education and their employability skills

Table 4:
\begin{tabular}{|l|r|r|c|c|}
\hline Model & R & R Square & $\begin{array}{c}\text { Adjusted R } \\
\text { Square }\end{array}$ & $\begin{array}{c}\text { Std. Error of the } \\
\text { Estimate }\end{array}$ \\
\hline 1 & $.695^{\mathrm{a}}$ & .567 & .516 & .69179 \\
\hline
\end{tabular}

a. Predictors: (Constant), Entrepreneurship Education

Source (Field Survey 2021)

From the regression analysis result shown in table 4, it was found that: $R$ value is $(0.695)$, R-square (0. 567), adjusted R-square (0.516) and the standard error of estimate is (0.69179).

The high value of $\mathrm{R}$ indicates a stronger relationship between entrepreneurship education and employability skills values of the variables. In other words, the $\mathrm{R}$ value depicts that entrepreneurship education accounted for $(69.5 \%)$ of the variation in employability skills. Also, the $\mathrm{R}^{2}$ value $(0.567)$ means that $56.7 \%$ of the variation in employability skills was explained by entrepreneurship education. This implies that entrepreneurship education contributes about $51.6 \%$ to the employability skills acquired while the remaining $48.4 \%$ is due to other variables that are not accounted for in the model.

Table 5:

ANOVA $^{\mathrm{a}}$

\begin{tabular}{|ll|r|r|r|r|r|}
\hline Model & & Sum of Squares & Df & Mean Square & F & \multicolumn{1}{c|}{ Sig. } \\
\hline 1 & Regression & 56.032 & 1 & 56.032 & 42.805 & \\
& Residual & 234.447 & 179 & 1.309 & & \\
& Total & 290.479 & 180 & & & \\
& & & & & \\
\hline
\end{tabular}

a. Dependent Variable: Employability Skills

b. Predictors: (Constant), Entrepreneurship Education

The ANOVA table above shows that the p-value $=0.000<0.05$ (sig.). Since p-value $<$ 0.05 thus the rejection of the null hypothesis that entrepreneurship education does not significantly determine employability skills and the alternative that entrepreneurship education significantly determine employability skills.

Table 6:

Coefficients $^{\mathrm{a}}$

\begin{tabular}{|c|c|c|c|c|c|c|}
\hline \multirow{2}{*}{\multicolumn{2}{|c|}{ Model }} & \multicolumn{2}{|c|}{ Unstandardized Coefficients } & $\begin{array}{c}\text { Standardized } \\
\text { Coefficients }\end{array}$ & \multirow[b]{2}{*}{$\mathrm{T}$} & \multirow[b]{2}{*}{ Sig. } \\
\hline & & $\mathrm{B}$ & Std. Error & Beta & & \\
\hline & (Constant) & 1.311 & .199 & & 6.584 & .000 \\
\hline & GenderDiversity & .272 & .059 & .259 & 4.650 & .000 \\
\hline
\end{tabular}

a. Dependent Variable: Employability Skills

Source (Field Survey, 2021)

Table 6 shows that employability skills is equal to 1.311 when all other variables are held to zero. Employability skills would increase by 0.272 when there is an entrepreneurship education by one unit, while other variables remain constant. However, the result shows that entrepreneurship education has positive and significant effect $(\mathrm{B}=0.259, \mathrm{t}$-value $=$ $4.650 \mathrm{p}<0.05)$. This implies that entrepreneurship education influence the employability 
skills acquired. This result is in line with the study of Afolabi etal (2017) affirmed that self-employment skills acquired by graduate is as a result of the quality of instruction given to students in entrepreneurship education by their lecturers.

\section{Discussion of Findings}

This finding revealed that entrepreneurship curriculum contents contain information on how students can identify and shape opportunities, new business concepts and bring through entrepreneurship, entrepreneurship curriculum develop operational plans, fund and launch ventures and grow new enterprises, Students actively engaged in teaching and learning process because they have been engaged in business through entrepreneurship curriculum. The finding of this study corroborated the finding of Bilic, Prka, and Vidovic (2011) who described entrepreneurship curriculum as a mechanism employed for the structured reproduction of entrepreneurial culture with emphasis on critical independent thinking and entrepreneurship development.

More so, this study also revealed that the various employability skills acquired by the graduate of tertiary institution after completing their course on entrepreneurship education helps them to be self-employed. This is in agreement with Afolabi etal (2017) who argued that employability skills acquired by graduates stimulates them to be self-employed after graduation.

\section{Conclusion and Recommendation}

This study shows that entrepreneurship education is a good policy on employability skills acquisition among students which makes them to be self-sustenance after graduation. It further shows that entrepreneurship education stimulates students' interest in entrepreneurial activities and also helps in building new business concepts. At this level, the emphasis on entrepreneurial education was perceived as an additional push for redesigning the entire tertiary school curriculum to maximize productivity at home. To improve the employability and self-sufficiency of Nigerian graduates, entrepreneurship education is an essential method. Nevertheless, new evidence suggests policy envisioned has not effectively fulfilled its stated aims, one of which is to develop entrepreneurial skills in Nigerian graduates at whatever level of higher education for self-reliance and employability in Nigeria. The study revealed that the fast-paced nature of the economies further mounts pressure on tertiary institutions in Nigeria to meet up with the growing needs and expectations of students and the society in order to ensure self-reliance, job creation and economic and development which entrepreneurship education can addressed if properly implemented. The study concluded among others that undergraduates in Nigeria's tertiary institutions are given both academic and practical entrepreneurship education as a way to cultivate the individual's desire and skill for better self-reliance and job creation in the society.

The following recommendations were made based on the findings of the study:

i. More institutions should include entrepreneurship courses in their curricula and must ensure that all students irrespective of their academic specialization study entrepreneurship. Entrepreneurship education should be aligned in accordance to the skills and abilities of students in order to be able to identify and exploit existing opportunities around them.

ii. The learning environment should be such that will be conducive enough for learning and practice in order to encourage students to pursue entrepreneurship after graduation 
by ensuring that they undertake a business project while in school. This therefore helps to build the entrepreneurship behavior of students in which student's exhibit entrepreneurial traits such as risk taking, innovating new ideas having a clear vision for the business.

iii.Entrepreneurship lecturers should introduce and use innovative/modern methods in teaching students of higher institutions the art and practice of entrepreneurship. This therefore can be done by ensuring that the right facilities are in place and the lecturers must be qualified and equipped with adequate knowledge and skills.

\section{Limitation of the Study and Future Direction}

The use of appropriate techniques for selection of the sample size was one of the limitation to this study, though through various expert in the field of evaluation and measurement, we were guided on the appropriate methodology to use in carrying out the activities for better result. The issue of finance was also bottleneck to this research work as we spent a lot to get the right information on this study, this led to the large number in carrying out the research work so that the burden of finance can be shared for ease.

Based on the limitation of this study, future research work should be directed to other higher institutions in Nigeria for better results, more tertiary institutions should be used for better result on this research study. More relevant topics on entrepreneurship education should be used as research study in the future since the aim of government is to reduce unemployment level in the country though creation of more jobs through entrepreneurship.

\section{References}

Afolabi, M. O., Kareem, F. A., Okubanjo, I. O.Ogunbanjo, O. A. \& Aninkan, O. O. (2017). Effect of Entreprenuership Education on Self- Employment Inititiatives among Nigerian Science and Technology Students. Journal of Education and Practice, 2(15): 44-51.

Agbim, E. Oriarewo, Y. \& Owocho, L. (2013). Entrepreneurial Studies: The Dynamic Research Front of a Developing Social Science. Entrepreneurship Theory and Practice, 30(3): 75-398.

Agi, P. \& Yellowe, D. (2013). Start-up Motivations and Growth Intentions of Minority Nascent Entrepreneurs. Journal of Small Business Management, 48(2): 174-196.

Ajayi, A. I. \& Afolabi, F. O. (2009). The Role of Tertiary Education in National Development: The Nigerian Scenerio. Journal of Teacher Education, 10: 34-36.

Asiyai, G. (2013). Entrepreneurship Education: Correspondence between Practices of Nascent Entrepreneurs and Textbook Prescriptions for Success. Academy of Management Learning and Education, 7(1): 56-70.

Bassey, U. U. \& Archibong, I. A. (2005). Assuring Quality Graduate Output Through Entrepreneurial Oriented Education in Nigerian University. Nigerian Journal of Curriculum Studies, 12(3), 18-23

Becker, G. S. (1964). Human capital. New York: The National Bureau of Economic Research.

Bilic, I., Prka A. \& Vidovic G. (2011). How does Education Influence Entrepreneurship Orientation? A Case Study of Croatia. Management Journal, 16(1) pp. 115-128. 
Boyi, A. A. (2014). Education and Sustainable National Development in Nigeria: Challenge and Way Forward. International Letters of Social and Humanistic Sciences, 14: 65-72.

Douglas, E. J. \& Shepherd, D. A. (2005). Entrepreneurial Human Capital and Self Employment Decision. Paper Presented at the Entrepreneurial Research Exchange, Swinburne University of Technology, Melbourne, Australia.

Dragoni, R. (2019). Entrepreneurship and New Venture Creation. In EChuta (Ed.). Small Enterprises and Entrepreneurship Development Dakar: Amalion Publishing. ISBN: 9782359260144.

Enu, D. B. (2012). Enhancing Entrepreneurial Education in Nigeria. American Journal of Social Issues and Humanities, 2(4), 232-239

Gafar, M. Kasim, R. \& Martin, D. (2013). Entrepreneurial Idea Development to Business Start-up: Teaching Methodological Approach. IOSR Journal of Research and Method in Education, 1(4): 46-56.

Ibitomi, T. \& Adeleke, O.J. (2020). Analyses of entrepreneurship education on entrepreneurial intention among undergraduate students in Nigeria. Journal of Business and Innovation Research, 8(8), 1-8

Lovat, T. (2013). Values Education Programs. In Hattie, J. \& Anderman, E. (Eds.), International Guides to Student Achievement. Pp. 279-281.

Mwasalwiba, E. S. (2010). Entrepreneurship Education: A Review of Its Objectives, Teaching Methods and Impact Indicators. Education and Training, 52, 20-47.

NEEDS. (2004). National Economic Empowerment and Development Strategy publication.

Olorundare, S. \& Kayode, D. J. (2014). Entrepreneurial Education in Nigerian Universities: Tool for National Transformation. Asia Pacific Journal of Educators and Education, Vol.29, 155-175

Orji, K. E. \& Job, M. (2013). The Role of Education in National Development: NigerianExperience. European Scientific Journal, 9(28) pp. 1857-7881.

Rahman, T. (2012), Opportunity Recognition and Idea Generation. Available@ @ Http:/Www.entrepreneurshipinabox.Com/1257/Opportunity-Recognition-Idea Generation

Schwarts, M. S. (2016). Ethical Decision Making Theory: An Integrated Approach. Journal of Business Ethics, 139 (4): 755-776

Shulman, L. S. \& Shulman J. H. (2004). How and What Teachers Learn: A shifting Perspective. Journal of Curriculum Studies, 36(2), 257-271.

Twumasi, Y. (2013). Preservation and Use of Indigenous Knowledge in Primary Healthcare among The Alternative Healthcare Practitioners in Oyo State, Nigeria. Proceedings of 2nd International Conference on Education and Social Sciences. 